\title{
Science Literacy in Early Childhood
}

\author{
Cihad Șentürk ${ }^{1}$ \\ ${ }^{1}$ (Child development department, Higher Health School/ Bilecik Şeyh Edebali University, Turkey)
}

\begin{abstract}
This study was conducted to determine and compare science literacy levels of children in early childhood period in terms of various variables. Survey model was used in the study which was conducted with 211 children who attend pre-schools in Bilecik, Turkey. As data collection tool, Early Childhood Science Education Content Standards Scale (SCSS) was used and as a result of data analysis, it was found that the children participating in the study had medium level of science literacy. In terms of the variables of age, number of siblings, the education background of the parents and science materials the participants have in their houses, a statistically meaningful difference was found in the science literacy scores of the children. In terms of the variable of gender, a statistically meaningful difference was not found in the science literacy scores of the children.
\end{abstract}

Keywords: Science literacy, science education, early childhood

\section{Introduction}

Children are born with a sense of wonder and exploration in order to make sense of the environment they live in and the world, as well. They have also a potential for learning by interacting with their environment (NRC, 2012). However, the children, besides their existing schema, gain science knowledge like preserving food for survival and some skills like drying, curing, etc. through the help of more knowledgeable adults (Mayer, 2004, NRC, 2007). The skills like observing, exploring and discovering are important and fundamental for science teaching and learning in the early childhood education. It is argued that an effective science education in the pre-school period fosters children's curiosity and enjoyment while exploring the environment and that it becomes a foundation for science education in the primary and secondary education (NSTA, 2002).

According to the National Science Teachers Association (2002, 2009), there are some key principles for preschool teachers to consider while teaching science:

- Children have potential for engaging in scientific practices and develop understanding at a conceptual stage.

- In order for young children to learn science, adults have a very important role. Adults can engage in such a process by asking questions to children, giving explanations to the questions of children, supporting children's learning and exploratory attempts, arranging the difficulty levels of information.

- Young children are in need of various opportunities that lead them to science exploration and discovery and they learn well if they are given such opportunities to explore and experience science (Bosse, Jacobs, and Anderson, 2009; NAEYC, 2013).

- Young children can get science skills and knowledge in formal settings (in schools thorough lesson plans) and informal settings (at home).

- It takes time for young children to develop science skills and knowledge. For example, it may take several weeks for young children to understand natural events like thunders, rain, flooding, etc.

- If young children are engaged in experimental learning setting prepared by adults, they can develop their science skills and knowledge. During experiments, children can ask questions, explore new information and can build upon their previous knowledge.

When the studies are examined, it can be seen that the numbers of the studies on science literacy levels of children are quite limited. The studies are generally on the importance of science education in early childhood period (Roth, 2013; Siraj-Blatchford, 2001; Trundle, 2009; Watters et al., 2001; Hamlin and Wisneski, 2013), program development and evaluation (Broström, 2015; Hong et al., 2013; Worth, 2010), teaching methods (Saçkes et al., 2012) the opinions of teachers on science education (Yllmaztekin and Erden 2011; Y1lmaztekin and Erden, 2016). It is believed that since this study aims to determine science literacy levels of children, it will support the literature in the field. In order to find solutions to some very important problems like climate changes, air pollution, global warming, wasting energy sources, environmental pollution, we should create awareness for our children and get them have high levels of science literacy. This study is believed to guide teachers, educators, program development experts, families and societies to foster science literacy levels of children in early childhood period. 


\subsection{Study Aim}

This study was conducted to determine the science literacy levels of children in early childhood and to compare these levels based on different variables. With the aim of determining the effects of specific variables on children's science literacy, the answers to the following questions were sought:

1. What are the science literacy levels of children in early childhood (ages 4-6)?

2. Is there a meaningful difference in the science literacy levels of children in early childhood based on a) gender, b) age, c) number of siblings, d) mother's educational background, e) father's educational background and $\mathrm{g}$ ) the presence of science materials in their homes?

\section{Method}

In this part of the his study, which was conducted to determine the science literacy levels of children in early childhood and to compare these levels based on different variables, the research method, study group, type and source of data, data collection tools and statistical analysis which were used in the study will be presented.

\subsection{Research Model}

This is a descriptive study which was conducted through the use of a screening model (survey). The screening method is a research method which aims to describe a past or a current situation exactly (Karasar, 2007; Cohen, Manion and Morrison, 2008). Children's science literacy levels and whether they differ in terms of gender, age, number of siblings, mother's educational background, father's educational background, family income and the presence of science materials in the participant children's homes were described using this method.

\subsection{Study Sample/Participants}

The study was conducted with 211 preschool children who voluntarily participated in the study, in Bilecik, Turkey, during the 2016-2017 academic year. Bilecik, in which the study was conducted, is located in northwestern Turkey and has a population of 57,000 people, most of whom are from middle-income families. This city generally presents limited opportunities, thus people often move elsewhere in Turkey. The demographic characteristics of the participant children are shown in Table 1. below.

Table 1. Demographic Characteristics of Participant Children

\begin{tabular}{|c|c|c|c|c|c|c|c|}
\hline \multirow{2}{*}{\multicolumn{2}{|c|}{ VARIABLES }} & \multicolumn{2}{|c|}{ Number of Child } & \multirow{2}{*}{\multicolumn{2}{|c|}{ DEĞIŞSENLER }} & \multicolumn{2}{|c|}{ Number of Child } \\
\hline & & f & $\%$ & & & $\mathbf{f}$ & $\%$ \\
\hline \multirow[t]{2}{*}{ Gender } & Girl & 112 & 53,1 & \multirow{5}{*}{$\begin{array}{l}\text { Educational } \\
\text { Background of } \\
\text { Father }\end{array}$} & Primary & 51 & 24,2 \\
\hline & Boy & 99 & 46,9 & & Secondary & 18 & 8,5 \\
\hline \multirow[t]{3}{*}{ Age } & 4 age & 67 & 31,8 & & High School & 89 & 42,2 \\
\hline & 5 age & 70 & 33,2 & & Graduate & 36 & 17,1 \\
\hline & 6 age & 74 & 35,1 & & Master & 17 & 8,1 \\
\hline \multirow{5}{*}{$\begin{array}{l}\text { Number of } \\
\text { Siblings }\end{array}$} & No Sibling & 48 & 22,7 & \multirow[t]{6}{*}{ Family Income } & $1000-1500 t^{*}$ & 18 & 8,5 \\
\hline & 1 sibling & 82 & 38,9 & & $1500-2000 t$ & 38 & 18,0 \\
\hline & 2 siblings & 43 & 20,4 & & $2000-2500 t$ & 51 & 24,2 \\
\hline & 3 siblings & 22 & 10,4 & & $2500-3000 t$ & 50 & 23,7 \\
\hline & 4 siblings and more & 16 & 7,6 & & $3000-3500 t$ & 40 & 19,0 \\
\hline \multirow{5}{*}{$\begin{array}{l}\text { Educational } \\
\text { Background } \\
\text { of Mother }\end{array}$} & Primary & 63 & 29,9 & & $3500 t$ and more & 14 & 6,6 \\
\hline & Secondary & 32 & 15,2 & \multirow{4}{*}{$\begin{array}{l}\text { The Presence of } \\
\text { Science } \\
\text { Materials in } \\
\text { Their Homes }\end{array}$} & Quite a lot & 39 & 18,5 \\
\hline & High School & 81 & 38,4 & & Adequate & 75 & 35,5 \\
\hline & Graduate & 26 & 12,3 & & Inadequate & 51 & 24,2 \\
\hline & Master & 9 & 4,3 & & None & 46 & 21,8 \\
\hline Total & & 211 & 100 & Total & & 211 & 100 \\
\hline
\end{tabular}

As seen in Table 1., $53.1 \%$ ( $\mathrm{n}=112$ ) of the participant children were girls, and $46.9 \%$ ( $\mathrm{n}=99$ ) were boys. Among the sample, $31.8 \%(\mathrm{n}=67)$ were at the age of four; $33.2 \%(\mathrm{n}=70)$ were at the age of five, and $35.1 \%$ $(\mathrm{n}=74)$ were at the age of six. In terms of number of siblings of the children, $22.7 \%(\mathrm{n}=70)$ do not have any siblings; $38.9 \%(\mathrm{n}=82)$ have one sibling; $20.4 \%(\mathrm{n}=43)$ have two siblings; $10.4 \%(\mathrm{n}=22)$ have three siblings, and $7.6 \%$ have four siblings. Regarding their mothers' educational backgrounds, $29.9 \%(\mathrm{n}=63)$ had a primary school degree; $15.2 \%(\mathrm{n}=32)$ had a secondary school degree; $38.4 \%(\mathrm{n}=81)$ had a high school degree; $12.3 \%(\mathrm{n}=26)$ had a graduate degree, and $4.3 \%(\mathrm{n}=9)$ had a master's degree. Regarding their fathers' educational backgrounds, $24.2 \%(n=51)$ had a primary school degree; $8.5 \%(n=18)$ had a secondary school degree; $42.2 \%(n=89)$ had a high school degree; $17.1 \%(\mathrm{n}=36)$ had a graduate degree, and $8.1 \%(\mathrm{n}=17)$ had a master's degree.

* Turkish lira symbol 
To the family income of the participant children, $8.5 \%(\mathrm{n}=18)$ of the children's families earn 10001500 t per month; $18 \%(\mathrm{n}=38)$ earn $1500-2000 \star$ per month; $24.2 \%(\mathrm{n}=51)$ earn $2000-2500$ t per month; $23.7 \%$ $(\mathrm{n}=50)$ earn $2500-3000 t$ per month; $19 \%(\mathrm{n}=40)$ earn 3000-3500 $t$ per month and $6.6 \%(\mathrm{n}=14)$ earn $3500 t$ or more per month. In a review of the variable reflecting the presence of science materials in the children's homes, it was found that $18.5 \%(\mathrm{n}=39)$ of the children possessed quite a lot of science materials; $35.5 \%(\mathrm{n}=75)$ possessed sufficient science materials; $24.2 \%(\mathrm{n}=51)$ possessed insufficient science materials, and $21.8 \%(\mathrm{n}=46)$ possessed no science materials in their homes.

\subsection{Data Collection Tools}

In the study, the Early Childhood Science Education Content Standards Scale (SCSS) which was developed by Taştepe and Temel (2013) and a personal information form, which was developed by the researcher with the aim of collecting necessary information about the participant children were used. The scale includes gains related to science and measures children's science literacy levels. Some of the items in the scale are presented in Table 2. below.

Table 2. Sample Items from Early Childhood Science Education Content Standards Scale

\begin{tabular}{|c|l|}
\hline $\begin{array}{l}\text { Item Number } \\
\text { in the Scale }\end{array}$ & \multicolumn{1}{|c|}{ Scale Item } \\
\hline 2 & S/he differentiates right/wrong actions towards living things such as watering/not watering plants etc. \\
\hline 7 & $\begin{array}{l}\text { S/he can distinguish the detrimental effects of situations on living things such as gum which is flung to ground can } \\
\text { be supposed as a food by birds, harmful food/drink can influence people' health etc. }\end{array}$ \\
\hline 12 & S/he forecasts meteorological situations such as rainy, sunny or snowy, on the basis of his/her experiences. \\
\hline 17 & $\begin{array}{l}\text { S/he searches natural laws such as throwing something to ground many times so as to observe the law of gravity } \\
\text { and makes generalizations for every item. }\end{array}$ \\
\hline 23 & $\begin{array}{l}\text { S/he identifies similarities and differences between natural objects like cotton, feather, wood etc. and man- } \\
\text { made objects like plastic, Styrofoam, paper etc. }\end{array}$ \\
\hline 28 & $\begin{array}{l}\text { S/he identifies the characteristics of sound such that if it is used in different situations like empty space, } \\
\text { microphone etc., it can sound high, low, deep, sharp etc. }\end{array}$ \\
\hline 31 & S/he talks about her/his observations related to day and night. \\
\hline
\end{tabular}

Totally possessing 31 items, the Early Childhood Science Education Content Standards Scale (SCSS) consists of three sub dimensions: life sciences, physical sciences and world and space sciences. The general Cronbach Alpha reliability coefficient of the scale was measured as .94. The scale rates children's science literacy proficiencies as always (5), often (4), sometimes (3), rarely (2) and never (1) (Taştepe \& Temel, 2013). The scale items were completed by children's teachers, families or with the researcher through taking children's proficiencies in the related item into consideration. As seen in Table 2., there were scientific gains in the scale which are expected to be shown by children in early childhood. The lowest score that can be obtained in the scale is 31 while the highest is 155 . The children who score 120 or above are acknowledged as excellent in terms of science literacy.

\subsection{Data Analysis}

The data obtained from Early Childhood Science Education Content Standards Scale (SCSS), which was applied so as to determine children's science literacy levels in early childhood period, was analyzed via frequency (f), percent $(\%)$, average $(\bar{x})$, standard deviation $(s d)$, t-test an one-way ANOVA, and through the use of SPSS packet program. In the case the ANOVA results were significant, the Scheffe test, which is one of the post-hoc multi comparison tests, was used in order to determine the source of the difference.

\section{Findings}

In this part of the paper, the findings which were revealed following the analysis and different interpretations related to these findings are presented. First, the science literacy levels of the participant children in early childhood period were determined and the results are given in Table 3. below.

Table 3. Science Literacy Levels of Children in Early Childhood

\begin{tabular}{|l|c|c|c|c|}
\hline $\begin{array}{l}\text { Early Childhood Science Education Content } \\
\text { Standards Scale (SCSS) }\end{array}$ & $n$ & $\bar{x}$ & $\bar{x} / k$ & $S d$ \\
\hline Life Sciences & 211 & 37.12 & 3.09 & .77 \\
\hline Physical Sciences & 211 & 26.89 & 2.98 & .97 \\
\hline World and Space Sciences & 211 & 32.24 & 3.22 & .79 \\
\hline General & 211 & 96.26 & 3.17 & .80 \\
\hline
\end{tabular}


In a review of Table 3., the children were found to score $\bar{x}=37.12(\bar{x} / \mathrm{k}=3.09)$ in the life sciences sub dimension; $\bar{x}=26.89(\bar{x} / \mathrm{k}=2.98)$ in physical sciences sub dimension, and $\bar{x}=32.24(\bar{x} / \mathrm{k}=3.22)$ from the world and space sciences sub dimension of Early Childhood Science Education Content Standards Scale (SCSS). And, the children were found to score $\bar{x}=96.26(\bar{x} / \mathrm{k}=3.17)$ in the scale in general. According to these findings, children's behaviors related to science are in the level of "sometimes" (3). Considering the total score the children obtained from the general scale ( $\bar{x}=96.26$ ), it can be said that the children have a medium level of science literacy. The children's science literacy scores based on gender are demonstrated in Table 4. below.

Table 4. The Comparison of Children's Science Literacy Scores based on Gender

\begin{tabular}{|c|c|c|c|c|c|c|c|}
\hline $\begin{array}{l}\text { Early Childhood Science Education } \\
\text { Content Standards Scale (SCSS) }\end{array}$ & Gender & $n$ & $\bar{x}$ & $s d$ & $d f$ & $t$ & $p$ \\
\hline \multirow[t]{2}{*}{ Life Sciences } & Girl & 112 & 36.63 & 9.146 & \multirow[t]{2}{*}{209} & \multirow[t]{2}{*}{-.816} & \multirow[t]{2}{*}{.416} \\
\hline & Boy & 99 & 37.68 & 9.595 & & & \\
\hline \multirow[t]{2}{*}{ Physical Sciences } & Girl & 112 & 27.18 & 8.640 & \multirow[t]{2}{*}{209} & \multirow[t]{2}{*}{.514} & \multirow[t]{2}{*}{.608} \\
\hline & Boy & 99 & 26.56 & 8.902 & & & \\
\hline \multirow[t]{2}{*}{ World and Space Sciences } & Girl & 112 & 32.66 & 7.618 & \multirow[t]{2}{*}{209} & \multirow[t]{2}{*}{.833} & \multirow[t]{2}{*}{.406} \\
\hline & Boy & 99 & 31.75 & 8.280 & & & \\
\hline
\end{tabular}

According to $t$ test result shown in Table 4., there were found no significant differences in early childhood period children's science literacy scores from the "life sciences" sub dimension based on gender $\left[t_{(209)}=-.816, \mathrm{p}>.05\right]$. Additionally, the differences seen in the "physical sciences" sub dimension were not significant $\left[t_{(209)}=-.514, \mathrm{p}>.05\right]$. And similarly, no significant differences were found in the "world and space sciences" sub dimension $\left[t_{(209)}=-.833, \mathrm{p}>.05\right]$. From these findings it can be inferred that children's science literacy levels do not show any difference in terms of gender. The arithmetic averages and standard deviation values related to children's science literacy level scores on the basis of gender are presented in Table 5. below. Also, the findings related to F test results, which was conducted to test whether the differences in children's science literacy levels average scores are statistically meaningful, are presented in the table.

Table 5. The Comparison of Children's Science Literacy Scores on the basis of Age

\begin{tabular}{|c|c|c|c|c|c|c|c|c|c|c|}
\hline $\begin{array}{l}\text { Early Childhood } \\
\text { Science Education } \\
\text { Content Standards } \\
\text { Scale (SCSS) } \\
\end{array}$ & Age & $n$ & $\bar{x}$ & $s d$ & $\begin{array}{l}\text { Source of } \\
\text { Variance }\end{array}$ & $\begin{array}{l}\text { Sum of } \\
\text { Squares }\end{array}$ & $d f$ & $\begin{array}{l}\text { Mean } \\
\text { Square }\end{array}$ & $\mathrm{F}$ & $p$ \\
\hline \multirow[t]{3}{*}{ Life Sciences } & 4 age & 67 & 2.81 & .835 & $\begin{array}{l}\text { Between } \\
\text { Groups }\end{array}$ & 8.359 & 2 & 4.180 & \multirow[t]{3}{*}{7.294} & \multirow[t]{3}{*}{$.001^{*}$} \\
\hline & 5 age & 70 & 3.16 & .731 & $\begin{array}{l}\text { Within } \\
\text { Groups }\end{array}$ & 119.193 & 208 & .573 & & \\
\hline & 6 age & 74 & 3.28 & .704 & Total & 127.552 & 210 & & & \\
\hline \multirow[t]{3}{*}{ Physical Sciences } & 4 age & 67 & 2.74 & 1.035 & $\begin{array}{l}\text { Between } \\
\text { Groups }\end{array}$ & 6.734 & 2 & 3.367 & \multirow[t]{3}{*}{3.653} & \multirow[t]{3}{*}{$.028^{*}$} \\
\hline & 5 age & 70 & 3.02 & .936 & $\begin{array}{l}\text { Within } \\
\text { Groups }\end{array}$ & 191.707 & 208 & .922 & & \\
\hline & 6 age & 74 & 3.17 & .909 & Total & 198.441 & 210 & & & \\
\hline \multirow[t]{3}{*}{$\begin{array}{l}\text { World and Space } \\
\text { Sciences }\end{array}$} & 4 age & 67 & 3.12 & .865 & $\begin{array}{l}\text { Between } \\
\text { Groups }\end{array}$ & 1.245 & 2 & .622 & \multirow[t]{3}{*}{.989} & \multirow[t]{3}{*}{.374} \\
\hline & 5 age & 70 & 3.22 & .770 & $\begin{array}{l}\text { Within } \\
\text { Groups }\end{array}$ & 130.822 & 208 & .629 & & \\
\hline & 6 age & 74 & 3.31 & .744 & Total & 132.067 & 210 & & & \\
\hline
\end{tabular}

$* p<.05$

According to the one-way ANOVA results conducted for children's science literacy scores on the basis of age, there were statistically meaningful differences found in the "life sciences" sub dimension $\left[F_{(2-208)}=7.294\right.$, $\mathrm{p}<.05]$ and in the "physical sciences" sub dimension $\left[\mathrm{F}_{(2-208)}=3.653, \mathrm{p}<.05\right]$. However, no statistically significant results were found in the "World and space sciences" sub dimension of the scale $\left[F_{(2-208)}=.989, p<.05\right]$. The Scheffe test, which is one of the post-hoc multi variable comparison tests, was applied to determine the source of this difference found in the "life sciences" and "physical sciences" sub dimensions on the basis of age, and the data related to the Scheffe test results is show in Table 6. below. 
Table 6. Scheffe Test Results of the Differences among Children's Science Literacy Scores on the basis of Age

\begin{tabular}{|c|c|c|c|c|c|c|c|}
\hline $\begin{array}{l}\text { Early Childhood Science Education } \\
\text { Content Standards Scale (SCSS) }\end{array}$ & $n$ & $\bar{x}$ & $s d$ & Age & 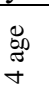 & 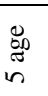 & 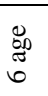 \\
\hline \multirow[t]{3}{*}{ Life Sciences } & 67 & 2.81 & .835 & 4 age & & * & * \\
\hline & 70 & 3.16 & .731 & 5 age & * & & \\
\hline & 74 & 3.28 & .704 & 6 age & * & & \\
\hline \multirow[t]{3}{*}{ Physical Sciences } & 67 & 2.74 & 1.035 & 4 age & & & * \\
\hline & 70 & 3.02 & .936 & 5 age & & & \\
\hline & 74 & 3.17 & .909 & 6 age & * & & \\
\hline
\end{tabular}

According to the results of the Scheffe test, the meaningful difference in the "life sciences" sub dimension was found to be between children ages four, five and six. In a review of arithmetic averages of both children ages four and five, the five-year-old children's arithmetic scores $(\bar{x}=3.16)$ were revealed to be higher than those of the four-year old's average scores $(\bar{x}=2.81)$. Similarly, the six-year old children's arithmetic scores $(\bar{x}=3.28)$ were found to be higher than the four-year-old's average scores $(\bar{x}=2.81)$. In this sense, it can be claimed that in the "life sciences" sub dimension, five and six-year-old children possess higher levels of science literacy than four-year-olds. In Table 7, the arithmetic averages and standard deviation values related to children's science literacy level scores based on number siblings are presented. And again, Table 7. shows the results of the F test, which was conducted to reveal whether the differences found in children's science literacy scores were significant.

Table 7. The Comparison of Children's Science Literacy Scores on the basis of Number of Siblings

\begin{tabular}{|c|c|c|c|c|c|c|c|c|c|c|}
\hline $\begin{array}{l}\text { Early Childhood } \\
\text { Science Education } \\
\text { Content Standards } \\
\text { Scale (SCSS) } \\
\end{array}$ & $\begin{array}{l}\text { Number of } \\
\text { Siblings }\end{array}$ & $n$ & $\bar{x}$ & $s d$ & $\begin{array}{l}\text { Source of } \\
\text { Variance }\end{array}$ & $\begin{array}{l}\text { Sum of } \\
\text { Squares }\end{array}$ & $d f$ & $\begin{array}{l}\text { Mean } \\
\text { Square }\end{array}$ & $\mathrm{F}$ & $p$ \\
\hline \multirow[t]{5}{*}{ Life Sciences } & No & 48 & 3.15 & .727 & \multirow{2}{*}{$\begin{array}{l}\text { Between } \\
\text { Groups }\end{array}$} & \multirow[t]{2}{*}{12,065} & \multirow[t]{2}{*}{4} & \multirow[t]{2}{*}{3.016} & \multirow[t]{5}{*}{5.380} & \multirow[t]{5}{*}{$.000 *$} \\
\hline & 1 siblings & 82 & 3.26 & .787 & & & & & & \\
\hline & 2 siblings & 43 & 3.03 & .664 & \multirow{2}{*}{$\begin{array}{l}\text { Within } \\
\text { Groups }\end{array}$} & \multirow[t]{2}{*}{115,488} & \multirow[t]{2}{*}{206} & \multirow[t]{2}{*}{.561} & & \\
\hline & 3 siblings & 22 & 2.98 & .800 & & & & & & \\
\hline & 4 or more & 16 & 2.34 & .746 & Total & 127,552 & 210 & & & \\
\hline \multirow[t]{5}{*}{ Physical Sciences } & No & 48 & 3.23 & .888 & \multirow{2}{*}{$\begin{array}{l}\text { Between } \\
\text { Groups }\end{array}$} & \multirow[t]{2}{*}{18,255} & \multirow[t]{2}{*}{4} & \multirow[t]{2}{*}{4.564} & \multirow[t]{5}{*}{5.217} & \multirow[t]{5}{*}{$.001 *$} \\
\hline & 1 siblings & 82 & 3.09 & .969 & & & & & & \\
\hline & 2 siblings & 43 & 2.81 & .900 & \multirow{2}{*}{$\begin{array}{l}\text { Within } \\
\text { Groups }\end{array}$} & \multirow[t]{2}{*}{180,186} & \multirow[t]{2}{*}{206} & \multirow[t]{2}{*}{.875} & & \\
\hline & 3 siblings & 22 & 3.03 & 1.016 & & & & & & \\
\hline & 4 or more & 16 & 2.08 & .864 & Total & 198,441 & 210 & & & \\
\hline \multirow{5}{*}{$\begin{array}{l}\text { World and Space } \\
\text { Sciences }\end{array}$} & No & 48 & 3.31 & .719 & \multirow{2}{*}{$\begin{array}{l}\text { Between } \\
\text { Groups }\end{array}$} & \multirow[t]{2}{*}{6,878} & \multirow[t]{2}{*}{4} & \multirow[t]{2}{*}{1.719} & \multirow[t]{5}{*}{2.829} & \multirow[t]{5}{*}{$.026^{*}$} \\
\hline & 1 siblings & 82 & 3.36 & .780 & & & & & & \\
\hline & 2 siblings & 43 & 3.08 & .838 & \multirow{2}{*}{$\begin{array}{l}\text { Within } \\
\text { Groups }\end{array}$} & \multirow[t]{2}{*}{125,189} & \multirow[t]{2}{*}{206} & \multirow[t]{2}{*}{.608} & & \\
\hline & 3 siblings & 22 & 3.14 & .765 & & & & & & \\
\hline & 4 or more & 16 & 2.72 & .801 & Total & 132,067 & 210 & & & \\
\hline
\end{tabular}

$* p<.05$

In terms of number of siblings, to the one-way ANOVA results, there were found statistically meaningful differences in the "life sciences" sub scale $\left[\mathrm{F}_{(4-206)}=5.380, \mathrm{p}<.05\right]$; in the "physical sciences" sub dimension $\left[\mathrm{F}_{(4-206)}=5.217, \mathrm{p}<.05\right]$ and in the "world and space sciences" sub dimension $\left[\mathrm{F}_{(4-206)}=2.829, \mathrm{p}<.05\right]$. With the aim of determining the source of the significant differences found in all sub dimensions, the Scheffe test was applied, and the data related to the test results are given in Table 8.

Tablo 8. Scheffe Test Results of the Differences among Children's Science Literacy Scores on the basis of Number of Siblings

\begin{tabular}{|c|c|c|c|c|c|c|c|c|c|}
\hline $\begin{array}{l}\text { Early Childhood Science } \\
\text { Education Content } \\
\text { Standards Scale (SCSS) }\end{array}$ & $n$ & $\bar{x}$ & $s d$ & Number of Siblings & $\stackrel{\circ}{\stackrel{\infty}{\Xi}}$ & 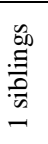 & 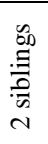 & $\begin{array}{l}\mathscr{\infty} \\
: \frac{0}{0} \\
\infty \\
m\end{array}$ & 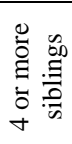 \\
\hline \multirow[t]{5}{*}{ Life Sciences } & 48 & 3.15 & .727 & No siblings & & & & & $*$ \\
\hline & 82 & 3.26 & .787 & 1 siblings & & & & & $*$ \\
\hline & 43 & 3.03 & .664 & 2 siblings & & & & & $*$ \\
\hline & 22 & 2.98 & .800 & 3 siblings & & & & & \\
\hline & 16 & 2.34 & .746 & 4 or more siblings & $*$ & $*$ & $*$ & & \\
\hline
\end{tabular}




\begin{tabular}{|c|c|c|c|c|c|c|c|}
\hline \multirow[t]{5}{*}{ Physical Sciences } & 48 & 3.23 & .888 & No siblings & & & $*$ \\
\hline & 82 & 3.09 & .969 & 1 siblings & & & * \\
\hline & 43 & 2.81 & .900 & 2 siblings & & & \\
\hline & 22 & 3.03 & 1.016 & 3 siblings & & & \\
\hline & 16 & 2.08 & .864 & 4 or more siblings & * & $*$ & \\
\hline \multirow{5}{*}{$\begin{array}{l}\text { World and Space } \\
\text { Sciences }\end{array}$} & 48 & 3.31 & .719 & No siblings & & & * \\
\hline & 82 & 3.36 & .780 & 1 siblings & & & * \\
\hline & 43 & 3.08 & .838 & 2 siblings & & & \\
\hline & 22 & 3.14 & .765 & 3 siblings & & & \\
\hline & 16 & 2.72 & .801 & 4 or more siblings & * & $*$ & \\
\hline
\end{tabular}

According to the Scheffe test results, the meaningful differences found in the "life sciences" sub dimension were between the children with four or more siblings, and the children with no siblings, or the children with one or two siblings. Considering the average scores of the children with no siblings $(\bar{x}=3.15)$, it was revealed that it was higher than the average scores of the children with four or more siblings $(\bar{x}=2.34)$. The average scores of the children with one sibling $(\bar{x}=3.26)$ were higher than the ones with four or more siblings $(\bar{x}=2.34)$. Similarly, the average scores of the children with two siblings $(\bar{x}=3.03)$ were found to be higher than the ones with four or more siblings $(\bar{x}=2.34)$. In the light of these findings, the children with four or more siblings can be said to be less science literate in the "life sciences" sub dimension than the ones without siblings, or the ones with one or two siblings.

Following the Scheffe test, it was revealed that the meaningful difference found in the "physical sciences" sub dimension were between the children with four or more siblings, and the ones with no siblings, and the ones with one sibling. The average scores of the ones with no siblings $(\bar{x}=3.23)$ were found to be higher than the average scores of the children with four or more siblings $(\bar{x}=2.08)$. The average scores of the ones with one sibling $(\bar{x}=3.09)$ were found to be higher than the average scores of the children with four or more siblings $(\bar{x}=2.08)$. Hence, the children with four or more siblings can be said to be less science literate in the "physical sciences" sub dimension than the ones with no siblings, or the ones with one sibling.

The meaningful differences found in the "world and space sciences" sub dimension were between the children with four or more siblings, and the children with no siblings, and the ones with one sibling. Considering the average scores of the children with no siblings $(\bar{x}=3.31)$, they were found to have higher scores than the ones with four or more siblings $(\bar{x}=2.72)$. Additionally, the average scores of the children with one sibling $(\bar{x}=3.36)$ were revealed to be higher than the ones with four or more siblings $(\bar{x}=2.72)$. In light of these findings, the children with four or more siblings can be said to be less science literate in the "world and physical sciences" sub dimension than the ones with no sibling, or the ones with one sibling. The arithmetic averages and standard deviation values related to children's science literacy scores on the basis of their mothers' educational backgrounds are demonstrated in Table 9. The table also shows the F test results which were applied to see whether the differences in the scores were meaningful.

Table 9. The Comparison of Children's Science Literacy Scores on the basis of Mother's Educational Background

\begin{tabular}{|c|c|c|c|c|c|c|c|c|c|c|}
\hline $\begin{array}{l}\text { Early Childhood } \\
\text { Science Education } \\
\text { Content Standards } \\
\text { Scale (SCSS) }\end{array}$ & $\begin{array}{l}\text { Mother's } \\
\text { Educational } \\
\text { Background }\end{array}$ & $n$ & $\bar{x}$ & $s d$ & $\begin{array}{l}\text { Source of } \\
\text { Variance }\end{array}$ & $\begin{array}{l}\text { Sum of } \\
\text { Squares }\end{array}$ & $d f$ & $\begin{array}{l}\text { Mean } \\
\text { Square }\end{array}$ & $\mathrm{F}$ & $p$ \\
\hline \multirow[t]{5}{*}{ Life Sciences } & Primary & 63 & 3.05 & .829 & \multirow{2}{*}{$\begin{array}{l}\text { Between } \\
\text { Groups }\end{array}$} & \multirow[t]{2}{*}{3.121} & \multirow[t]{2}{*}{4} & \multirow[t]{2}{*}{.780} & \multirow[t]{5}{*}{1.292} & \multirow[t]{5}{*}{.274} \\
\hline & Secondary & 32 & 3.01 & .800 & & & & & & \\
\hline & High School & 81 & 3.04 & .721 & \multirow{2}{*}{$\begin{array}{l}\text { Within } \\
\text { Groups }\end{array}$} & \multirow[t]{2}{*}{124.432} & \multirow[t]{2}{*}{206} & \multirow[t]{2}{*}{.604} & & \\
\hline & Graduate & 26 & 3.33 & .825 & & & & & & \\
\hline & Master & 9 & 3.44 & .634 & Total & 127.552 & 210 & & & \\
\hline \multirow[t]{5}{*}{ Physical Sciences } & Primary & 63 & 2.67 & 1.064 & \multirow{2}{*}{$\begin{array}{l}\text { Between } \\
\text { Groups }\end{array}$} & \multirow[t]{2}{*}{11.197} & \multirow[t]{2}{*}{4} & \multirow[t]{2}{*}{2.799} & \multirow[t]{5}{*}{3.080} & \multirow[t]{5}{*}{$.017^{4}$} \\
\hline & Secondary & 32 & 3.01 & .977 & & & & & & \\
\hline & High School & 81 & 3.07 & .879 & \multirow{2}{*}{$\begin{array}{l}\text { Within } \\
\text { Groups }\end{array}$} & \multirow[t]{2}{*}{187.244} & \multirow[t]{2}{*}{206} & \multirow[t]{2}{*}{.909} & & \\
\hline & Graduate & 26 & 3.23 & .944 & & & & & & \\
\hline & Master & 9 & 3.55 & .645 & Total & 198.441 & 210 & & & \\
\hline \multirow{5}{*}{$\begin{array}{l}\text { World and Space } \\
\text { Sciences }\end{array}$} & Primary & 63 & 2.93 & .869 & \multirow{2}{*}{$\begin{array}{l}\text { Between } \\
\text { Groups }\end{array}$} & \multirow[t]{2}{*}{9.517} & \multirow[t]{2}{*}{4} & \multirow[t]{2}{*}{2.379} & \multirow[t]{5}{*}{3.999} & \multirow[t]{5}{*}{.004} \\
\hline & Secondary & 32 & 3.22 & .706 & & & & & & \\
\hline & High School & 81 & 3.32 & .759 & \multirow{2}{*}{$\begin{array}{l}\text { Within } \\
\text { Groups }\end{array}$} & \multirow[t]{2}{*}{122.550} & \multirow[t]{2}{*}{206} & \multirow[t]{2}{*}{.595} & & \\
\hline & Graduate & 26 & 3.52 & .709 & & & & & & \\
\hline & Master & 9 & 3.55 & .424 & Total & 132.067 & 210 & & & \\
\hline
\end{tabular}


According to the results of the one-way ANOVA which was conducted on the basis of number of siblings variable, there was no statistically meaningful difference in the "life sciences" sub dimension $\left[\mathrm{F}_{(4-}\right.$ $\left.{ }_{206}=1.292, \mathrm{p}>.05\right]$ while there were found meaningful differences in the sub dimensions of "physical sciences" $\left[\mathrm{F}_{(4-206)}=3.080, \mathrm{p}<.05\right]$ and "world and space sciences" $\left[\mathrm{F}_{(4-206)}=3.999, \mathrm{p}<.05\right]$.

In order to determine the source of the meaningful difference found between "physical sciences" and "world and space sciences" sub dimensions, the Schffe test was applied, and the related findings are shown in Table 10 below.

Table 10. Scheffe Test Results for the Children's Science Literacy Scores on the basis of Mothers' Educational Background

\begin{tabular}{|c|c|c|c|c|c|c|c|c|c|}
\hline $\begin{array}{l}\text { Early Childhood Science } \\
\text { Education Content Standards } \\
\text { Scale (SCSS) }\end{array}$ & $n$ & $\bar{x}$ & $s d$ & $\begin{array}{l}\text { Mother's Educational } \\
\text { Background }\end{array}$ & $\stackrel{\vec{E}}{\Xi}$ & 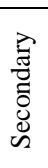 & 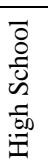 & 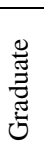 & 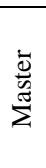 \\
\hline \multirow[t]{5}{*}{ Physical Sciences } & 63 & 2.67 & 1.064 & Primary & & & & $*$ & $*$ \\
\hline & 32 & 3.01 & .977 & Secondary & & & & & \\
\hline & 81 & 3.07 & .879 & High School & & & & & \\
\hline & 26 & 3.23 & .944 & Graduate & $*$ & & & & \\
\hline & 9 & 3.55 & .645 & Master & $*$ & & & & \\
\hline \multirow[t]{5}{*}{ World and Space Sciences } & 63 & 2.93 & .869 & Primary & & & & $*$ & $*$ \\
\hline & 32 & 3.22 & .706 & Secondary & & & & & \\
\hline & 81 & 3.32 & .759 & High School & & & & & \\
\hline & 26 & 3.52 & .709 & Graduate & $*$ & & & & \\
\hline & 9 & 3.55 & .424 & Master & $*$ & & & & \\
\hline
\end{tabular}

According to the results of the Scheffe test, the meaningful differences found in the "physical sciences" sub dimension were between the children whose mothers have a primary school degree, and the children whose mothers have graduate and master's degrees. The average scores of the children whose mothers have graduate and a master's degrees $(\bar{x}=3.55)$ were found to be higher than the children whose mothers have a primary degree $(\bar{x}=2.67)$. Similarly, the average scores of the children whose mothers have a graduate degree $(\bar{x}=$ 3.23 ) were found to be higher than the ones whose mothers have primary degrees $(\bar{x}=2.67)$. In this context, the children whose mothers have graduate or master's degrees can be said to be more science literate in the "physical sciences" sub dimension than the children whose mothers have a primary school degree.

The difference found in the "world and space sciences" sub dimension was between the children whose mothers have a primary school degree and the ones whose mothers have a graduate or master's degree. The average scores of the children whose mothers have master's degrees $(\bar{x}=3.55)$ were found to be higher than the children whose mothers have primary school degrees $(\bar{x}=2.93)$. Similarly, the average scores of the children whose mothers have a graduate degree $(\bar{x}=3.52)$ were found to be higher than the children whose mothers have a primary school degree $(\bar{x}=2.93)$. Thus, the children whose mothers have a graduate or master's degree can be said to be more science literate in the "world and space sciences" sub dimension than the children whose mothers have a primary school degree. Table 11. presents the arithmetic averages and standard deviation values related to children's science literacy scores on the basis of father's educational background. The table also reflects the results of the $\mathrm{F}$ test which was applied to test whether the differences in scores were meaningful.

Table 11. The Comparison of Children's Science Literacy Scores on the basis of Father's Educational Background

\begin{tabular}{|c|c|c|c|c|c|c|c|c|c|c|}
\hline $\begin{array}{l}\text { Early Childhood } \\
\text { Science Education } \\
\text { Content Standards } \\
\text { Scale (SCSS) }\end{array}$ & $\begin{array}{c}\text { Father's } \\
\text { Educational } \\
\text { Background }\end{array}$ & $n$ & $\bar{x}$ & $s d$ & $\begin{array}{l}\text { Source of } \\
\text { Variance }\end{array}$ & $\begin{array}{l}\text { Sum of } \\
\text { Squares }\end{array}$ & $d f$ & $\begin{array}{l}\text { Mean } \\
\text { Square }\end{array}$ & F & $p$ \\
\hline \multirow[t]{5}{*}{ Life Sciences } & Primary & 51 & 2.81 & .764 & \multirow{2}{*}{$\begin{array}{l}\text { Between } \\
\text { Groups }\end{array}$} & \multirow[t]{2}{*}{18.376} & \multirow[t]{2}{*}{4} & \multirow[t]{2}{*}{4.594} & \multirow[t]{5}{*}{8.668} & \multirow[t]{5}{*}{$.000^{*}$} \\
\hline & Secondary & 18 & 2.76 & .672 & & & & & & \\
\hline & High School & 89 & 3.08 & .805 & \multirow{2}{*}{$\begin{array}{l}\text { Within } \\
\text { Groups }\end{array}$} & \multirow[t]{2}{*}{109.176} & \multirow[t]{2}{*}{206} & \multirow[t]{2}{*}{.530} & & \\
\hline & Graduate & 36 & 3.28 & .544 & & & & & & \\
\hline & Master & 17 & 3.90 & .542 & Total & 127.552 & 210 & & & \\
\hline \multirow[t]{5}{*}{ Physical Sciences } & Primary & 51 & 2.73 & .894 & \multirow{2}{*}{$\begin{array}{l}\text { Between } \\
\text { Groups }\end{array}$} & \multirow[t]{2}{*}{20.679} & \multirow[t]{2}{*}{4} & \multirow[t]{2}{*}{5.170} & \multirow[t]{5}{*}{5.991} & \multirow[t]{5}{*}{$.000 *$} \\
\hline & Secondary & 18 & 2.75 & .982 & & & & & & \\
\hline & High School & 89 & 2.93 & .939 & \multirow{2}{*}{$\begin{array}{l}\text { Within } \\
\text { Groups }\end{array}$} & \multirow[t]{2}{*}{177.762} & \multirow[t]{2}{*}{206} & \multirow[t]{2}{*}{.863} & & \\
\hline & Graduate & 36 & 3.14 & 1.043 & & & & & & \\
\hline & Master & 17 & 3.93 & .586 & Total & 198.441 & 210 & & & \\
\hline
\end{tabular}


Science Literacy in Early Childhood

\begin{tabular}{|c|c|c|c|c|c|c|c|c|c|c|}
\hline \multirow{5}{*}{$\begin{array}{l}\text { World and Space } \\
\text { Sciences }\end{array}$} & Primary & 51 & 3.01 & .747 & \multirow{2}{*}{$\begin{array}{l}\text { Between } \\
\text { Groups }\end{array}$} & \multirow[t]{2}{*}{12.275} & \multirow[t]{2}{*}{4} & \multirow[t]{2}{*}{3.069} & \multirow[t]{5}{*}{5.277} & \multirow[t]{5}{*}{$.000^{*}$} \\
\hline & Secondary & 18 & 2.96 & .856 & & & & & & \\
\hline & High School & 89 & 3.17 & .778 & \multirow{2}{*}{$\begin{array}{l}\text { Within } \\
\text { Groups }\end{array}$} & \multirow[t]{2}{*}{119.792} & \multirow[t]{2}{*}{206} & \multirow[t]{2}{*}{.582} & & \\
\hline & Graduate & 36 & 3.46 & .759 & & & & & & \\
\hline & Master & 17 & 3.84 & .605 & Total & 18.376 & 4 & 4.594 & & \\
\hline
\end{tabular}

* $p<.05$

According to the results of the one-way ANOVA which was conducted on the basis of father's educational background, there were found statistically meaningful differences in the "life sciences" sub dimension $\left[\mathrm{F}_{(4-206)}=8.668, \mathrm{p}<.05\right]$, in the "physical sciences" sub dimension $\left[\mathrm{F}_{(4-206)}=5.991, \mathrm{p}<.05\right]$ and in the "world and space sciences" sub dimension $\left[\mathrm{F}_{(4-206)}=5.277, \mathrm{p}<.05\right]$. With the aim of determining the source of the meaningful differences in all sub dimensions, the Schffe test was applied, and the related findings are shown in Table 12. below.

Tablo 12. Scheffe Test Results for the Children's Science Literacy Scores on the basis of Fathers' Educational Background

\begin{tabular}{|c|c|c|c|c|c|c|c|c|c|}
\hline $\begin{array}{l}\text { Early Childhood Science } \\
\text { Education Content Standards } \\
\text { Scale (SCSS) }\end{array}$ & $n$ & $\bar{x}$ & $s d$ & $\begin{array}{l}\text { Father's Educational } \\
\text { Background }\end{array}$ & 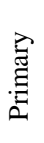 & 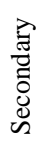 & 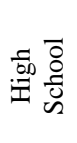 & 胥 & 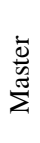 \\
\hline \multirow[t]{5}{*}{ Life Sciences } & 51 & 2.81 & .764 & Primary & & & & & * \\
\hline & 18 & 2.76 & .672 & Secondary & & & & & $*$ \\
\hline & 89 & 3.08 & .805 & High School & & & & & $*$ \\
\hline & 36 & 3.28 & .544 & Graduate & & & & & \\
\hline & 17 & 3.90 & .542 & Master & $*$ & $*$ & $*$ & & \\
\hline \multirow[t]{5}{*}{ Physical Sciences } & 51 & 2.73 & .894 & Primary & & & & & $*$ \\
\hline & 18 & 2.75 & .982 & Secondary & & & & & * \\
\hline & 89 & 2.93 & .939 & High School & & & & & $*$ \\
\hline & 36 & 3.14 & 1.043 & Graduate & & & & & \\
\hline & 17 & 3.93 & .586 & Master & $*$ & $*$ & $*$ & & \\
\hline \multirow[t]{5}{*}{ World and Space Sciences } & 51 & 3.01 & .747 & Primary & & & & & $*$ \\
\hline & 18 & 2.96 & .856 & Secondary & & & & & * \\
\hline & 89 & 3.17 & .778 & High School & & & & & $*$ \\
\hline & 36 & 3.46 & .759 & Graduate & & & & & \\
\hline & 17 & 3.84 & .605 & Master & $*$ & $*$ & $*$ & & \\
\hline
\end{tabular}

To the Scheffe test results, the difference found in the "life sciences" sub dimension was between the children whose fathers have a master's degree and the ones whose fathers have primary, secondary or high school degrees. The average scores of the children whose fathers have a master's degree $(\bar{x}=3.90)$ were found to be higher than the children whose fathers have a primary school degree $(\bar{x}=2.81)$. The average scores of the children whose fathers have a master's degree $(\bar{x}=3.90)$ were found to be higher than the children whose fathers have a a secondary school degree $(\bar{x}=2.76)$. The average scores of the children whose fathers have a master's degree $(\bar{x}=3.90)$, were found to be higher than the children whose fathers have a high school degree $(\bar{x}=3.08)$. Hence, the children whose fathers have a master's degree can be said to be more science literate in the "life sciences" sub dimension than the children whose fathers have primary, secondary or high school degrees.

The meaningful difference found in the "physical sciences" sub dimension was between the children whose fathers have a master's degree and the ones whose fathers have primary, secondary or high school degrees. The average scores of the children whose fathers have a master's degree $(\bar{x}=3.93)$ were found to be higher than the children whose fathers have a primary school degree $(\bar{x}=2.73)$. The average scores of the children whose fathers have a master's degree $(\bar{x}=3.93)$ were found to be higher than the children whose fathers have a secondary school degree $(\bar{x}=2.75)$. The average scores of the children whose fathers have a master's degree $(\bar{x}=3.93)$ were found to be higher than the children whose fathers have a high school degree $(\bar{x}=2.93)$. In this sense, the children whose fathers have a master's degree can be said to be more science literate in the "physical sciences" sub dimension than the children whose fathers have primary, secondary or high school degrees.

The meaningful difference found in the "world and space sciences" sub dimension was again between the children whose fathers have a master's degree and the ones whose fathers have primary, secondary or high 
school degrees. The average scores of the children whose fathers have a master's degree $(\bar{x}=3.84)$ were found to be higher than the children whose fathers have primary degree $(\bar{x}=3.01)$. The average scores of the children whose fathers have a master's degree $(\bar{x}=3.84)$ were found to be higher than the children whose fathers have a secondary school degree $(\bar{x}=2.96)$. The average scores of the children whose fathers have a master's degree $(\bar{x}=3.84)$ were found to be higher than the children whose fathers have a high school degree $(\bar{x}=3.17)$. In light of these findings, the children whose fathers have a master's degree can be said to be more science literate in the "world and space sciences" sub dimension than the children whose fathers have primary, secondary or high school degrees. Table 13. shows the arithmetic averages and standard deviation values related to children's science literacy scores based on the presence of science material in their homes. The table also demonstrates the results of the $\mathrm{F}$ test which was applied to test whether the differences in scores were meaningful.

Tablo 13. The Comparison of Children's Science Literacy Scores on the basis on the Presence of Science Material in Their Homes

\begin{tabular}{|c|c|c|c|c|c|c|c|c|c|c|}
\hline $\begin{array}{l}\text { Early Childhood } \\
\text { Science Education } \\
\text { Content Standards } \\
\text { Scale (SCSS) }\end{array}$ & $\begin{array}{l}\text { Presence of } \\
\text { Science } \\
\text { Material in } \\
\text { Their Homes }\end{array}$ & $n$ & $\bar{x}$ & $s d$ & $\begin{array}{l}\text { Source of } \\
\text { Variance }\end{array}$ & $\begin{array}{l}\text { Sum of } \\
\text { Squares }\end{array}$ & $d f$ & $\begin{array}{l}\text { Mean } \\
\text { Square }\end{array}$ & $\mathrm{F}$ & $p$ \\
\hline \multirow[t]{4}{*}{ Life Sciences } & Quite a lot & 39 & 3.80 & .380 & Between & 53.513 & 3 & 17.838 & \multirow[t]{4}{*}{49.870} & \multirow[t]{4}{*}{$.000^{*}$} \\
\hline & Sufficient & 75 & 3.17 & .659 & Within & 74.040 & 207 & .358 & & \\
\hline & Insufficient & 51 & 3.19 & .673 & \multirow[t]{2}{*}{ Total } & \multirow[t]{2}{*}{127.552} & \multirow[t]{2}{*}{210} & & & \\
\hline & No material & 46 & 2.25 & .550 & & & & & & \\
\hline \multirow[t]{4}{*}{ Physical Sciences } & Quite a lot & 39 & 3.93 & .389 & Between & 114.320 & 3 & 38.107 & \multirow[t]{4}{*}{93.771} & \multirow[t]{4}{*}{$.000^{*}$} \\
\hline & Sufficient & 75 & 3.22 & .744 & Within & 84.121 & 207 & .406 & & \\
\hline & Insufficient & 51 & 3.07 & .758 & \multirow[t]{2}{*}{ Total } & \multirow[t]{2}{*}{198.441} & \multirow[t]{2}{*}{210} & & & \\
\hline & No material & 46 & 1.71 & .436 & & & & & & \\
\hline \multirow{4}{*}{$\begin{array}{l}\text { World and Space } \\
\text { Sciences }\end{array}$} & Quite a lot & 39 & 3.92 & .325 & Between & 68.624 & 3 & 22.875 & \multirow[t]{4}{*}{74.634} & \multirow[t]{4}{*}{$.000^{*}$} \\
\hline & Sufficient & 75 & 3.39 & .632 & Within & 63.443 & 207 & .306 & & \\
\hline & Insufficient & 51 & 3.34 & .615 & \multirow[t]{2}{*}{ Total } & \multirow[t]{2}{*}{132.067} & \multirow[t]{2}{*}{210} & & & \\
\hline & No material & 46 & 2.21 & .491 & & & & & & \\
\hline
\end{tabular}

According to the results of the one-way ANOVA, which was conducted on the basis of the presence of science material at children's homes, there were found statistically meaningful differences in "life sciences" sub dimension $\left[\mathrm{F}_{(3-207)}=49.870, \mathrm{p}<.05\right]$, in the "physical sciences" sub dimension $\left[\mathrm{F}_{(3-207)}=93.771, \mathrm{p}<.05\right]$ and in the "world and space sciences" sub dimension $\left[\mathrm{F}_{(3-207)}=74.634, \mathrm{p}<.05\right]$. With the aim of determining the source of the meaningful differences in all sub dimensions, the Schffe test was applied, and the related findings are shown in Table 14. below.

Tablo 14. Scheffe Test Results for the Children's Science Literacy Scores on the basis on the Presence of Science Material in Their Homes

\begin{tabular}{|c|c|c|c|c|c|c|c|c|}
\hline $\begin{array}{l}\text { Early Childhood Science } \\
\text { Education Content } \\
\text { Standards Scale (SCSS) }\end{array}$ & $n$ & $\bar{x}$ & $s d$ & $\begin{array}{l}\text { Presence of Science } \\
\text { Material in Their } \\
\text { Homes }\end{array}$ & 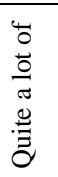 & 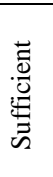 & 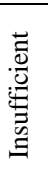 & 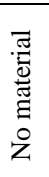 \\
\hline \multirow[t]{4}{*}{ Life Sciences } & 39 & 3.80 & .380 & Quite a lot of & & $*$ & $*$ & $*$ \\
\hline & 75 & 3.17 & .659 & Sufficient & & & & \\
\hline & 51 & 3.19 & .673 & Insufficient & & & & \\
\hline & 46 & 2.25 & .550 & No material & $*$ & $*$ & $*$ & \\
\hline \multirow[t]{4}{*}{ Physical Sciences } & 39 & 3.93 & .389 & Quite a lot of & & $*$ & $*$ & $*$ \\
\hline & 75 & 3.22 & .744 & Sufficient & & & & \\
\hline & 51 & 3.07 & .758 & Insufficient & & & & \\
\hline & 46 & 1.71 & .436 & No material & $*$ & $*$ & $*$ & \\
\hline \multirow[t]{4}{*}{ World and Space Sciences } & 39 & 3.92 & .325 & Quite a lot of & & $*$ & $*$ & $*$ \\
\hline & 75 & 3.39 & .632 & Sufficient & & & & \\
\hline & 51 & 3.34 & .615 & Insufficient & & & & \\
\hline & 46 & 2.21 & .491 & No material & $*$ & $*$ & $*$ & \\
\hline
\end{tabular}

According to the Scheffe test results, the difference found in the "life sciences" sub dimension was between the children possessing quite a lot of science materials in their homes and the ones possessing sufficient, insufficient science materials and the ones possessing no science materials in their homes. Also, there 
were found meaningful differences in science literacy scores of the children who have sufficient science materials at home and the ones who do not have any science materials at home. The average scores of the children who have quite a lot of science materials at their homes $(\bar{x}=3.80)$ were found to be higher than the children who have sufficient $(\bar{x}=3.17)$, insufficient $(\bar{x}=3.19)$ and no science materials at their homes $(\bar{x}=$ 2.25). In light of these findings, the children who have quite a lot of science materials at their homes can be said to be more science literate in "life sciences" sub dimension than the children who have sufficient, insufficient and no science materials at their homes. Additionally, the average scores of the children who have no science materials at their homes $(\bar{x}=2.25)$ were found to be lower than the average scores of the ones who have quite a lot of science materials at their homes $(\bar{x}=3.80)$, who have sufficient science materials at their homes $(\bar{x}=$ 3.17), and who have insufficient science materials at their homes $(\bar{x}=3.19)$. In this sense, the children who don't have any science materials at their homes can be said to be less science literate than the children who have quite a lot of, sufficient and insufficient science materials at their homes.

The meaningful difference found in "physical sciences" sub dimension was between the children who have quite a lot of science materials at their homes, and the ones who have sufficient, insufficient and no science materials at their homes. There were also found meaningful differences in science literacy scores of the children who have sufficient science materials at home and those who do not have any science materials at home. The average scores of the children who have quite a lot of science materials at their homes $(\bar{x}=3.93)$, were found to be higher than the children who have sufficient $(\bar{x}=3.22)$, insufficient $(\bar{x}=3.07)$ and no science materials at their homes $(\bar{x}=1.71)$. In this sense, the children who have quite a lot of science materials at their homes can be said to be more science literate in "physical sciences" sub dimension than the children who have sufficient, insufficient and no science materials at their homes. Besides, the average scores of the children who have no science materials at their homes $(\bar{x}=1.71)$ were found to be lower than the average scores of the ones who have quite a lot of science materials at their homes $(\bar{x}=3.93)$, who have sufficient science materials at their homes $(\bar{x}=3.22)$, and who have insufficient science materials at their homes $(\bar{x}=3.07)$. Hence, the children who do not have any science materials at their homes can be said to be less science literate in "physical sciences" sub dimension than the children who have quite a lot of, sufficient and insufficient science materials at their homes.

The significant difference found in the "world and space sciences" sub dimension was between the children, who have quite a lot of science materials at their homes, and the ones who have sufficient, insufficient and no science materials at their homes. There were also found meaningful differences in science literacy scores of the children who have sufficient science materials at home and the ones who do not have any science materials at home. The average scores of the children who have quite a lot of science materials at their homes $(\bar{x}=3.92)$, were found to be higher than the children who have sufficient $(\bar{x}=3.39)$, insufficient $(\bar{x}=3.34)$ and no science materials at their homes $(\bar{x}=2.21)$. In this context, the children who have quite a lot of science materials at their homes can be said to be more science literate in "world and space sciences" sub dimension than the children who have sufficient, insufficient and no science materials at their homes. Again, the average scores of the children who have no science materials at their homes $(\bar{x}=2.21)$ were found to be lower than the average scores of the ones who have quite a lot of science materials at their homes $(\bar{x}=3.92)$, who have sufficient science materials at their homes $(\bar{x}=3.39)$, and who have insufficient science materials at their homes $(\bar{x}=3.34)$. Thus, the children who don't have any science materials at their homes can be said to be less science literate in "world and space sciences" sub dimension than the children who have quite a lot of, sufficient and insufficient science materials at their homes.

\section{Discussion and Conclusion}

This study was conducted to determine the science literacy levels of children in early childhood stage and to compare these levels based on different variables. To the analysis results, the science literacy level scores of the participant children were found to be $\bar{x}=96.26(\bar{x} / \mathrm{k}=3.17)$. In this sense, the participant children can be said to have a medium level of science literacy. In the related literature, the number of studies concerning the determination of children's science literacy levels, especially the ones in early childhood stage, is quite inadequate. Especially in Turkey, although there have been adequate studies regarding teachers' opinions towards science education for children, teaching methods in science education, materials in this field etc. there seems to be almost no studies related to children's science literacy. Thus, this study is expected to significantly contribute to the related literature.

To the $\mathrm{t}$ test results, no meaningful difference was found in children's science literacy level scores on the basis of gender. In terms of age, one-way variance analysis results indicate statistically significant differences in the "life sciences" and "physical sciences" sub dimensions. The study findings suggest that the children at the age of five and six can be accepted as more science literate than those at the age of four. As a 
result of the fact that as the age rises, the mental development and developments at other sides improve, children interact with their surroundings more, which might in turn be said to influence their science literacy levels.

Regarding the number of siblings variable, one-way variance analysis results indicate statistically meaningful differences in children's science literacy level scores. In this sense, the scores of the children with four or more siblings were lower than other children's science literacy scores, which might stem from the fact that the high number of siblings results in lack of care and interest given to a child, financial opportunities provided, the increase in child's responsibility towards his siblings etc. In a review of the science literacy scores, the highest scores were found to belong to the children with no siblings or with one sibling, which might stem from the fact that these families can spare more time and financial opportunities for their children, that thee children are more free to act on the basis of their exploring senses, that they can make use of materials at home and in their environments more etc.

Regarding parents' educational background, the one-way variance analysis results demonstrate statistically meaningful differences in children's science literacy scores. The children whose fathers or mother have a graduate or a master's degree are seen to be more science literate than the others. Indeed, the high educational background of parents can signify that children can be provided various opportunities to experience science by their parents, which can be agreed to contribute positively to children's science literacy. Lastly, based on the presence of science materials in home, the one-way variance analysis results suggest statistically meaningful differences in children's science literacy scores. In this sense, the scores of the children who have quite a lot of science materials at their homes were higher than other children's scores. Thus, it can be said that these children are more science literate than the children who possess less science materials at their homes. Also, the opposite situation can be said for the children who do not have any science materials at their homes.

\section{Recommendations}

In early childhood, children are having a deep sense of curiosity and exploring. They want know and investigate the environment so they attempt to do various things. They try to satisfy their curiosity through tinkering with objects, tools, equipment, machines, drawers, cupboards, toys etc. in their homes or surroundings. Many families prefer to hinder these actions of children for fear that they would harm themselves or their surroundings. However, these attempts comprise the foundation of scientific thought. Children's sense of curiosity and exploring should not be hindered, they should be encouraged to do so, they should be provided with opportunities, experiences related materials and experiment settings, all of which would considerably contribute to their science literacy and to their scientific process skills.

During the implementation of the study, the researcher also found the chance to observe at schools, and to learn about scientific studies there. According to the observations of the researcher, there were no science materials at some schools or classrooms, or at some of them they were not adequate. Also, in many classes, science education was limited to specific corners in classes. However, science is everywhere. Scientific studies can be conducted anywhere. Even without buying any materials, scientific studies can be conducted. Scientific studies can be done through making use of waste materials, wood, paper, wax, fiber and numerous materials that we can count here now. Natural trips, camps, visits to zoos and botanic gardens, observations, practices made with water, mud, sand, clay and stone, and various similar studies can be conducted, and these activities can be maintained both at home and at school.

The places which provide children with experiences related to science have increased in Turkey recently. The number of the observation sides at playgrounds, small zoos, hobby gardens, and science houses including scientific materials, and science centers for children has risen. However, these opportunities are provided in big cities generally, thus it is of importance to establish these facilities even in small cities and rural areas. It is thought that providing children with opportunities in which they can work in the science field considerably contributes to their science literacy levels. The studies in literature proved that children who experience various things in a specific field are disposed to be more successful at that field. Through providing schools and families with necessary support, all children can be raised to be equipped with 21 st century skills, to possess scientific thought and as individuals who contribute to their country and humanity through his or her discoveries and inventions.

\section{References}

[1] Bosse, S., Jacobs, G. \& Anderson, T. L. (2009). Science in the air. Young Children, 10-15. Reprinted and retrieved at https://www.naeyc.org/files/tyc/file/V4N5/Science_in_the_air.pdf [Date of access: 07.01.2017].

[2] Broström, S. (2015). Science in Early Childhood Education. Journal of Education and Human Development 4(2/1), 107-124. Doi: 10.15640/jehd.v4n2_1a12.

[3] Hamlin, M. and Wisneski, D. B. (2012). Supporting the scientific thinking and inquiry of toddlers and preschoolers through play. Young Children, 82-88. Retrieved from http://www.naeyc.org/yc/files/yc/file/201205/Hamlin_YC0512.pdf [Date of access: 23.12.2016]. 
[4] Hong, Soo-Young; Torquati, Julia; and Molfese, Victoria J. (2013). Thory Guided Professional Development in Early Childhood Science Education. Faculty Publications form CYFS. Retrieved from http://digitalcommons.unl.edu/cyfsfacpub/29 [Date of access: 25.12.2016].

[5] Mayer, R. E. (2004). Should there be a three-strikes rule against pure discovery learning? The case for guided methods of instruction. American Psychologist, 59, 14-19.

[6] National Association for the Education of Young Children [NAEYC]. (2013). Early childhood program standards and accreditation criteria \& guidance for assessment. Retrieved from http://www.naeyc.org/files/academy/file/AllCriteriaDocument.pdf [Date of access: 11.01.2017].

[7] National Research Council [NRC]. (2012). A framework for K-12 science education: Practices, crosscutting concepts, and core ideas. Washington, DC: National Academies Press.

[8] National Research Council [NRC]. (2007). Taking science to school: Learning and teaching science in grades K-8. Washington, DC: National Academies Press.

[9] National Science Teachers Association [NSTA]. (2009). NSTA Position Statement: Parent Involvement in Science Learning. Retrieved from http://www.nsta.org/about/positions/parents.aspx [Date of access: 15.01.2017].

[10] National Science Teachers Association [NSTA]. (2002). NSTA Position Statement: Elementary School Science. Retrieved from http://www.nsta.org/about/positions/elementary.aspx [Date of access: 21.01.2017].

[11] Roth, W-M., Mafra Goulart, M. I. \& Plakitsi, K. (2013). Science education during early childhood. Switzerland: Springer International Publishing AG.

[12] Saçkes, M., Akman, B. \& Trundle, K. C. (2012). A science methods course for early childhood teachers: A model for undergraduate pre-service teacher education. Necatibey Faculty of Education Electronic Journal of Science and Mathematics Education, 6(2), 126.

[13] Siraj-Blatchford, J. (2001). Emergent Science and Technology in the Early Years. XXIII world congress of OMEP, Santiago Chile July $31^{\text {st }}$ to $4^{\text {th }}$ August, Diego Portales Convention Centre.

[14] Taştepe. T. \& Temel. F. (2013). Erken çocukluk dönemi fen ve matematik eğitimi içerik standartları değerlendirme araçlarının geliştirilmesi (geçerlik ve güvenirlik çalışmaları). Kastamonu eğitim dergisi. 21(4). 1625-1640.

[15] Trundle, K. C. (2009). Teaching science during the early childhood years. National Geographic Learning. Retrieved from http://ngl.cengage.com/assets/downloads/ngsci_pro0000000028/am_trundle_teach_sci_early_child_scl22-0429a.pdf [Date of access: 11.12.2016].

[16] Watters, James J., Diezmann, Carmel M., Grieshaber, Susan J. and Davis, Julie M. (2001) Enhancing science education for young children: A contemporary initiative. Australian Journal of Early Childhood 26(2), 1-7.

[17] Worth, K. (2010). Science in early childhood classrooms: Content and process. Early Childhood Research \& Practice. Retrieved from http://ecrp.illinois.edu/beyond/seed/worth.html [Date of access: 27.12.2016].

[18] Yilmaztekin, E. Ö. and Erden, F. T. (2011). Early childhood teachers' views about science teaching practices. Western Anatolia Journal of Educational Sciences (WAJES), Special Issue, 161-168.

[19] Yilmaztekin, E. Ö. and Erden, F. T. (2016). Investigating early childhood teachers' views on science teaching practices: the integration of science with visual art in early childhood settings. Early Child Development and Care. Doi: 10.1080/03004430.2016.1160899. 